\title{
A Method for Extracting and Purifying Streptomycin Suitable for Large-scale Production
}

\author{
By T. J. WOODTHORPE AND D. M. IRELAND \\ The Wellcome Physiological Research Laboratories, Beckenham, Kent
}

\begin{abstract}
SUMMARY: A method is described for extracting streptomycin from culture filtrates by adsorption on charcoal at $\mathrm{pH} 6-8$, elution with $1 \cdot 2 \%(\mathrm{v} / \mathrm{v})$ aqueous phosphoric acid, readsorption of the eluate on charcoal at $\mathrm{pH} 7$, elution with acidified methanol, followed by evaporation at reduced pressure and precipitation of streptomycin by dilution of the concentrated methanol eluate with 5 volumes acetone or amyl acetate. An indication is given of the order of recovery, and the potency of the product obtained. The stability of streptomycin under the conditions of $\mathrm{pH}$ and temperature to which it may be subjected during the extraction is outlined. The process has been carried out in pilot-scale production equipment handling $1500 \mathrm{l}$. batches of culture filtrate.
\end{abstract}

The aim of this work was to devise a method of extracting streptomycin from culture filtrates prepared by the method of Ainsworth, Brown, Marsden, Smith \& Spilsbury (1947) which could be applied to the large-scale and economic manufacture of the antibiotic. In particular, a method was required that could be carried out in an extraction plant previously used for penicillin production.

Extraction methods given by other workers can be summarized as follows:

(1) A. Adsorption on charcoal at $\mathrm{pH} 7.0$ and elution with $0.5 \% \mathrm{HCl}$ in methanol (Waksman \& Schatz, 1945; LePage \& Campbell, 1946; Carter, Clark, Dickman, Loo, Skell \& Strong, 1945).

B. Concentration of neutral eluate (LePage \& Campbell, 1946).

C. Precipitation of streptomycin hydrochloride, by addition of a large excess of ether or acetone to the eluates or concentrates (Waksman \& Schatz, 1945; LePage \& Campbell, 1946; Carter et al., 1945).

(2) Charcoal adsorption at low $\mathrm{pH}$ to remove pigments followed by extraction of the streptomycin as in 1 (LePage \& Campbell, 1946; Carter et al., 1945).

(3) Adsorption on charcoal at $\mathrm{pH} 7 \cdot 0$ followed by elution of water-free charcoal cake with anhydrous methanolic hydrogen chloride, concentration of neutral eluate and precipitation of the streptomycin hydrochloride with acetone (Waksman \& Schatz, 1945).

(4) A two-stage process involving solution of the first precipitate in water, adsorption on charcoal, elution with acid-methanol, concentration and precipitation (LePage \& Campbell, 1946).

The adaption of the foregoing processes to large-scale manufacturing conditions presented the following difficulties : $(a)$ the construction of acid-resistant plant; $(b)$ the use of large volumes of methanol, with consequent high cost of production; $(c)$ the production of large volumes of methanol-acetone mixtures, 
presenting difficulties of fractionation; $(d)$ the difficulty of recovering small weights of a hygroscopic product from large volumes of solvent.

Bearing in mind these difficulties, a process was developed along the following lines:

(1) Adsorption of the streptomycin from the culture filtrate on $1 \%(\mathrm{w} / \mathrm{v})$ activated charcoal at $\mathrm{pH}$ 6-8.

(2) Elution of the streptomycin from the charcoal with $1.2 \%(\mathrm{v} / \mathrm{v})$ aqueous phosphoric acid at $\mathrm{pH} \mathbf{1} \cdot \mathbf{0}-\mathbf{2} \cdot \mathbf{0}$.

(3) Adsorption of the streptomycin on $3-4 \%(\mathrm{w} / \mathrm{v})$ activated charcoal from the neutralized phosphate eluate at $\mathrm{pH} 7$.

(4) Elution of the streptomycin under anhydrous conditions with acidified methanol.

(5) Evaporation of the neutralized methanol eluate to one-eighth of its original volume.

(6) Precipitation of the streptomycin by dilution of the concentrate with acetone, or other precipitant of higher boiling-point, e.g. amyl acetate.

This process has some advantages. For example: (i) In the first stage of the extraction, streptomycin is eluted from the charcoal with dilute aqueous phosphoric acid, enabling stainless steel equipment to be used when volumes are large. (ii) The organic solvent elution stage is delayed until a considerable volume diminution has been effected, decreasing solvent requirements to at least one-tenth of those employed in other processes. (iii) Precipitation of streptomycin is not accomplished until volumes are comparatively small. (iv) The volume of methanol-acetone mixture produced during the process is at a minimum. (v) The use of aqueous phosphoric acid as an eluting agent gives pigment-free eluates and renders unnecessary the introduction of a special decolorizing stage.

\section{METHODS}

The method of streptomycin assay was a dilution test using Escherichia coli (Bacterium coli) as the test organism, and the unit employed was $1 \mu \mathrm{g}$. streptomycin base (Brown \& Young, 1947). It was necessary to remove methanol by evaporation from concentrated methanol solutions to avoid interference by the bactericidal properties of the alcohol. In practice, samples were evaporated under reduced pressure to $8 \%$ or less of their original volume and diluted back to the initial volume with distilled water. Unsatisfactory results were obtained with certain phosphate eluate samples, and data obtained for extraction efficiencies and potencies up to the phosphate eluate stage are approximations.

The potencies of the final dried products obtained from the pilot plant were also determined by a spectrographic assay method (unpublished) developed by Dr Tudor S. G. Jones of the Wellcome Chemical Research Laboratories (see Table 5).

Total solids were determined by drying in an oven at $70^{\circ}$ for $18 \mathrm{hr}$. Such results agreed satisfactorily with determinations made by drying by sublimation of the water from the frozen state. 


\section{LABORATORY-SCALE EXTRACTION}

Most of the work on adsorption and elution from charcoal was carried out on laboratory-size Metafilters (Metafiltration Ltd., Hounslow, Middlesex) designed to take a charge of $150 \mathrm{~g}$. charcoal and $115 \mathrm{~g}$. filter-aid. This gave a charcoal bed sufficient for a 15 l. culture filtrate cycle. The beds were washed with water prior to each elution and at the end of each complete and successive cycle.

The extraction process from culture filtrate to the first eluate may be referred to as stage 1 ; and from the first eluate to the final product as stage 2 . All volumes of washing liquids and eluants used in stage 1 are given as volumes/100 vol. of culture filtrate. For stage 2 , all volumes are given as volumes/100 vol. phosphate eluate. Thus a ' 40 volume' wash means, in stage 1 , washing with a volume of liquid $40 \%$ of the volume of culture filtrate taken, and in stage $2,40 \%$ of the volume of phosphate eluate. The ratio streptomycin to total solids ( $\mu \mathrm{g} . / \mathrm{mg}$.) is referred to as 'potency'.

After removal of the mycelial felts the culture fluid was clarified by filtration through cloth filters precoated with Hyflo Supercel (Johns Manville Ltd.). The culture filtrate assayed between 200 and $400 \mu \mathrm{g}$. streptomycin $/ \mathrm{ml}$. on harvesting (potency 6-18). The $\mathrm{pH}$ of the culture filtrates ranged between $\mathrm{pH} 6$ and 8 .

\section{Stage 1; First charcoal adsorption}

'Farnell 14' was found to be the most suitable active charcoal for the adsorption of streptomycin from these culture filtrates and allowed elutions to take place with suitable eluants. A level of $1 \%(\mathrm{w} / \mathrm{v})$ charcoal to culture filtrate volume appeared optimal for $\mathrm{pH}$ 6-8. Pigment adsorption increased, whilst total solid and streptomycin adsorption decreased below $\mathrm{pH} 6$, and at pH 2 almost pigment-free filtrates were obtained without appreciable adsorption of streptomycin. The effect of culture filtrate $\mathrm{pH}$ on streptomycin adsorption efficiency is indicated in Table 1.

Table 1. Effect of $\mathrm{pH}$ on streptomycin adsorption efficiency

Original titre of culture filtrate: $148 \mu \mathrm{g} . / \mathrm{ml}$. Adsorption on 'Farnell 14' charcoal: $1 \%$ $(\mathrm{w} / \mathrm{v})$.

$\begin{array}{ccc}\text { Streptomycin in culture } & \begin{array}{c}\text { Adtrate after } \\ \text { adsorption } \\ (\mu \mathrm{g} . / \mathrm{ml} .)\end{array} & \begin{array}{c}\text { Adsorption } \\ \text { efficiency } \\ (\%)\end{array} \\ 4.5 & 67 & 53 \\ 6 & 30 & 80 \\ 7 & <11 & >93 \\ 8 & <11 & >93 \\ 5 & <11 & >93\end{array}$

No differences in efficiency of adsorption of streptomycin were observed as between passing culture filtrates through static charcoal beds, and adsorption on charcoal suspensions. Similarly, static elution appeared as satisfactory as elution by suspension. Static charcoal beds used for successive adsorptions and elutions retained their efficiency, and no appreciable quantity of solid 
material accumulated in them. One bed could be used for at least seven complete operations. Table 2 indicates the total solid (mg./ml.) recovery between culture filtrate and eluate over seven successive cycles.

Table 2. The use of one charcoal bed for a series of adsorptions and elutions

\begin{tabular}{|c|c|c|c|c|c|c|c|c|}
\hline & \multicolumn{7}{|c|}{ Cycle } & \multirow[b]{2}{*}{ Mean } \\
\hline & 1 & 2 & 3 & 4 & 5 & 6 & 7 & \\
\hline $\begin{array}{l}\text { Culture filtrate }(500 \mathrm{ml} .) \text {; total solids } \\
(\mathrm{mg} . / \mathrm{ml} .)\end{array}$ & $18 \cdot 4$ & $18 \cdot 4$ & $18 \cdot 4$ & $18 \cdot 4$ & $18 \cdot 4$ & $18 \cdot 5$ & $18 \cdot 4$ & - \\
\hline $\begin{array}{l}\text { Spent culture filtrate }(500 \mathrm{ml} .) \text {; total } \\
\text { solids }(\mathrm{mg} . \mathrm{ml} .)\end{array}$ & - & $15 \cdot 4$ & $15 \cdot 9$ & $18 \cdot 4$ & $16 \cdot 0$ & $15 \cdot 6$ & $15 \cdot 4$ & 一. \\
\hline $\begin{array}{l}\text { Phosphate eluate (200 ml.); total } \\
\text { solids (mg./ml.) }\end{array}$ & - & $5 \cdot 7$ & $8 \cdot 8$ & $5 \cdot 8$ & $6 \cdot 0$ & $5 \cdot 8$ & $5 \cdot 7$ & - \\
\hline $\begin{array}{l}\text { Washwater }(200 \mathrm{ml} .) \text {; total solids } \\
(\mathrm{mg} \cdot / \mathrm{ml}) \text { ) }\end{array}$ & - & $2 \cdot 4$ & $2 \cdot 6$ & $3 \cdot 8$ & $2 \cdot 7$ & $3 \cdot 0$ & $2 \cdot 1$ & - \\
\hline \multicolumn{9}{|l|}{ Total solids of culture filtrate: } \\
\hline $\begin{array}{l}\text { Adsorbed on charcoal }(\%) \\
\text { Recovered in phosphate eluate }(\%)\end{array}$ & - & $\begin{array}{l}16 \\
12\end{array}$ & 13 & $\overline{13}$ & $\begin{array}{l}13 \\
13\end{array}$ & $\begin{array}{l}15 \\
13\end{array}$ & $\begin{array}{l}16 \\
12\end{array}$ & $\begin{array}{l}15 \\
13\end{array}$ \\
\hline
\end{tabular}

The effect of water washing the charcoal beds after the adsorption of streptomycin was studied. Approximately $30-40 \%$ of the adsorbed solids could be removed without appreciable loss of streptomycin. The progressive change in total-solids content of the effluent when water-washing the charcoal beds is indicated in Fig. 1. A 40 volume water-wash appears to be optimum.

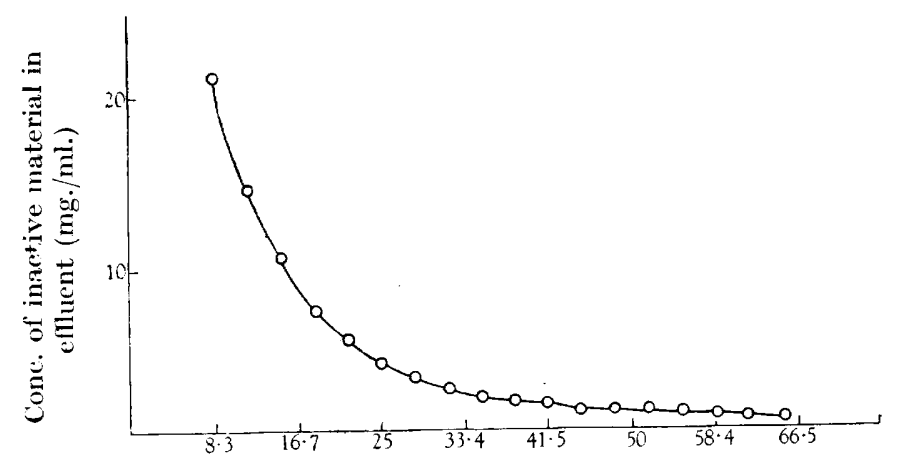

Water-wash volume as percentage of culture filtrate volume used

Fig. 1. Relation between water-wash volume and concentration of inactive material in effluent.

\section{Stage 1; Elution of first charcoal adsorbate}

The progressive change in streptomycin content and $\mathrm{pH}$ of the eluate on elution with $\mathbf{1} \cdot \mathbf{2} \%$ phosphoric acid is shown in Fig. 2 . The first $3-5$ volumes of eluate were almost inactive. Elution was complete with 15 volumes. Provided a 40 volume water-wash was introduced between the adsorption and elution, the phosphate eluates were almost colourless. Elution of the water-washed charcoal bed with acid-methanol gave pigmented eluates. 
An indication of the order of recovery and volume diminution obtained from culture filtrate to phosphate eluate is given in Table 3 . The potency of the phosphate eluate was estimated as 30-60, but the accuracy of the recovery figures is affected by difficulties experienced in assaying streptomycin in the presence of phosphate.

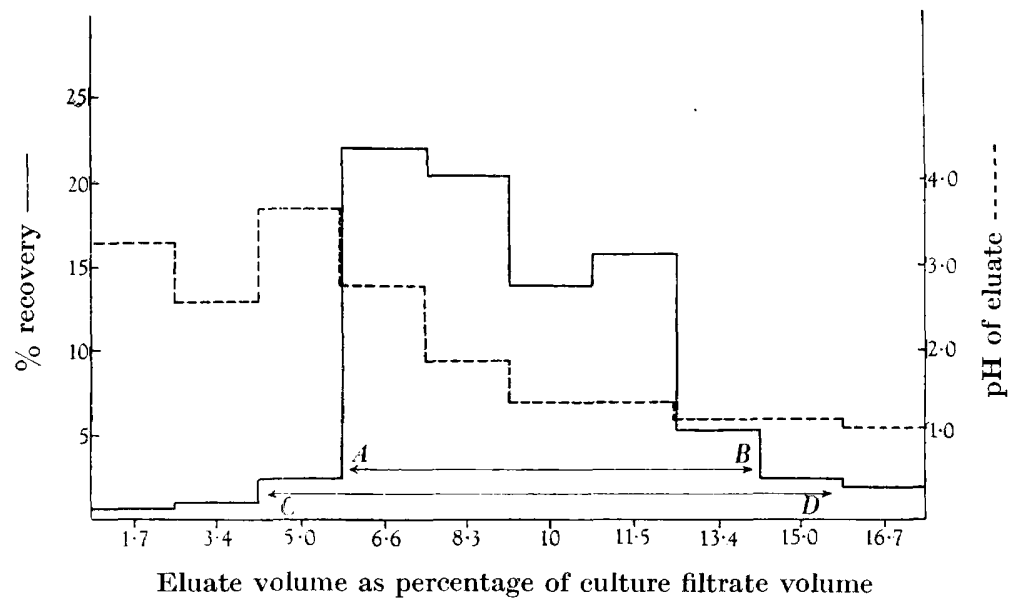

Fig. 2. The progressive change in streptomycin content (continuous line) and pH (broken line) during elution with $1.2 \%$ phosphoric acid. $\boldsymbol{A}-\boldsymbol{B}$, for $10,000 \mathrm{l}$. culture filtrate to 830 l. eluate, $8 \cdot 5 \%$ streptomycin loss; $C-D$, for 10,0001 . culture filtrate to $1200 \mathrm{l}$. eluate, $3 \cdot 6 \%$ streptomycin loss.

Table 3. Volume diminution for culture filtrate to phosphate eluate and \% recovery

$\begin{array}{lcccccc}\text { Culture filtrate volume (1) } & 15 & 15 & 15 & 15 & 15 \\ \text { Phosphate eluate volume (1) } & 2 \cdot 5 & 2 \cdot 0 & 2 \cdot 0 & 2 \cdot 0 & 2 \cdot 3 \\ \quad \text { Eluate volume as \% filtrate volume } & 16 & 13 & 13 & 13 & 15 & \\ & & & & & & \\ \text { Total streptomycin (g.): } & & & & & & \\ \text { In culture filtrate } & 1 \cdot 5 & 2 \cdot 27 & 2 \cdot 42 & 2 \cdot 42 & 1 \cdot 43 & \\ \text { In eluate } & 1 \cdot 10 & 1 \cdot 58 & 1 \cdot 46 & 1 \cdot 57 & 1 \cdot 18 & \\ \quad \text { \% recovery } \quad 73 & 68 & 61 & 65 & 82 & 69 \cdot 8 \\ \text { Culture filtrate: 'Titre }(\mu \mathrm{g} . / \mathrm{ml} .) & 100 & 151 & 161 & 161 & 95 & \end{array}$

Neutralization of the phosphate eluate with caustic soda gave heavy precipitates of calcium phosphate, calcium ion having been extracted from the charcoal bed during elution at low $\mathrm{pH}$. These precipitates were troublesome to handle, particularly on a manufacturing scale, and entailed an additional filtration. The amount of precipitate could be decreased, but never completely eliminated, by washing the charcoal beds with a large volume of dilute aqueous phosphoric acid prior to the adsorption of streptomycin. 


\section{Stage 2; Second charcoal adsorption and elution}

The readsorption of streptomycin from the neutralized phosphate eluate was effected, as at the first extraction stage, with Farnell 14 charcoal, and the subsequent elution was by means of acidified methanol. Both operations were carried out with the charcoal suspended in the liquor; 3-4 \% $(\mathrm{w} / \mathrm{v})$ charcoal was optimal.

Adsorption. After suspension for $30 \mathrm{~min}$. the charcoal was filtered off and the bed washed first with 40 volumes of water and finally with 40 volumes of neutral methanol. The purpose of the neutral methanol wash was to remove some inactive material and to lower the water content of the charcoal bed to a minimum. Failure to remove water from the charcoal resulted in sticky and hydrated precipitates of streptomycin hydrochloride at the precipitation stage.

Elution. This was effected by suspension of the washed charcoal in methanol containing $2 \%(\mathrm{v} / \mathrm{v})$ conc. hydrochloric acid $(\mathrm{pH} \mathbf{1} \cdot \mathbf{5}-\mathbf{2} \cdot 0)$ with agitation for $30 \mathrm{~min}$. 15 volumes of eluant were used, and while $2 \%(\mathrm{v} / \mathrm{v})$ of conc. $\mathrm{HCl}$ was usually adequate to bring the suspension to $\mathrm{pH} 1 \cdot 5$, it was advisable to check the $\mathrm{pH}$ after $15 \mathrm{~min}$. stirring, and to add more acid if required. The spent charcoal was removed by filtration and the charcoal bed washed three times on the filter with 5 volumes of acid-methanol. The bulked eluate and washings were adjusted to $\mathrm{pH} 6$ with $80 \%$ (w/v) caustic soda. Calcium phosphate was again precipitated, but the amount of this precipitate also could be decreased by pretreatment of the charcoal with aqueous acid. Recoveries and potencies for the second adsorption and elution are given in Table 4.

Table 4. Volume diminution phosphate eluate to methanol eluate and \% recovery

\begin{tabular}{|c|c|c|c|c|}
\hline $\begin{array}{l}\text { Phosphate eluate volume (1.) } \\
\text { Methanol eluate (l.) }\end{array}$ & $\begin{array}{l}2 \cdot 0 \\
0 \cdot 38\end{array}$ & $\begin{array}{l}2 \cdot 3 \\
0 \cdot 44\end{array}$ & $\begin{array}{l}2 \cdot 4 \\
0 \cdot 40\end{array}$ & \\
\hline $\begin{array}{l}\text { Methanol eluate vol. as \% phosphate } \\
\text { eluate vol. }\end{array}$ & 19 & 19 & 17 & \\
\hline $\begin{array}{r}\text { Total streptomycin (g.): In phosphate eluate } \\
\text { In methanol eluate }\end{array}$ & $\begin{array}{l}1 \cdot 57 \\
1.06\end{array}$ & $\begin{array}{l}1 \cdot 18 \\
0 \cdot 81\end{array}$ & $\begin{array}{l}1 \cdot 05 \\
0 \cdot 66\end{array}$ & \\
\hline$\%$ recovery & 68 & 69 & 62 & $66 \cdot 3$ \\
\hline Methanol eluate potency ( $\mu \mathrm{g} . / \mathrm{ml}$.) & 248 & 245 & - & \\
\hline
\end{tabular}

\section{Stage 2; Concentration of second eluate and separation of streptomycin hydrochloride}

The neutralized and filtered eluate was concentrated to one-eighth of its original volume by evaporation under reduced pressure at $30-40^{\circ}$ and refiltered. Some inactive material, mainly sodium chloride, was thrown out of solution during concentration and the streptomycin potencies increased in consequence. There was no appreciable inactivation of streptomycin during concentration; the $\mathrm{pH}$ tended to fall.

White flocculent precipitates of streptomycin hydrochloride were obtained 
by the addition to the filtered concentrates of five times their volume of commercial acetone. The precipitates were filtered off and dried under reduced pressure over sulphuric acid. Losses of streptomycin in the mother liquor were not more than $1 \%$ of that in the culture filtrate, provided the water content of the methanol-acetone mixture was at a minimum. No detectable increase in potency occurred during precipitation. The overall extraction efficiencies from culture filtrate to precipitate averaged $40 \%$, and the potency of the precipitate was $\mathbf{2 0 0 - 5 0 0 .}$

The solubility of the product in methanol was $10.9 \mathrm{~g} . / 100 \mathrm{ml}$., in ethanol $0.5 \mathrm{~g} . / 100 \mathrm{ml}$., and in methylated spirits $1.1 \mathrm{~g} . / 100 \mathrm{ml}$. The solubility of streptomycin hydrochloride in these solvents will be influenced to some extent by the water content, but it is apparent that, of the three solvents investigated, methanol alone is suitable as an eluting agent. With methanol eluates, care had to be taken to avoid concentration to such a degree that the solubility of streptomycin hydrochloride was exceeded.

The use of acetone as precipitant on a manufacturing scale would be uneconomic owing to the difficulties of fractionating mixtures of methanol and acetone. A search was made for alternative precipitants, of suitable availability, cost, boiling-point, solubility in methanol, water content at saturation, and ease of dehydration. Amyl acetate and monochlorobenzene were the most satisfactory and gave as good streptomycin recoveries as did acetone.

\section{Stability}

The stabilities of the crude culture filtrate, the methanol eluate and of aqueous solutions of streptomycin hydrochloride were investigated at various $\mathrm{pH}$ values and temperatures. The maximum stability of culture filtrates and aqueous and methanol solutions of streptomycin hydrochloride was in the range $\mathrm{pH} 3 \cdot 0-6 \cdot 0$. Aqueous solutions of streptomycin hydrochloride were kept at $\mathrm{pH} 1.0$ and $20^{\circ}$ for $173 \mathrm{hr}$. without loss of activity; aqueous and methanol solutions were kept for 33 days at $20^{\circ}$ and $\mathrm{pH} 7$, without any detectable inactivation. Material dried from the frozen state has been kept at $20^{\circ}$ for 67 days, without detectable loss of streptomycin content. Aqueous and methanol solutions of streptomycin hydrochloride were heated at $90^{\circ}$ for $7 \mathrm{hr}$. in the range $\mathrm{pH} \cdot 3 \cdot 0-6 \cdot 0$ without detectable loss of streptomycin content.

\section{PILOT-PLANT EXTRACTION}

Filtration and first adsorption. The culture fluid on the plant scale was harvested in batches of $1500 \mathrm{l}$. and was clarified by filtration through leaf cloth filters precoated with filter-aid; filter-aid was also continuously injected into the flow-line on the feed side of the filter. The temperature of the liquor was decreased to $+3^{\circ}$ in a brine-cooled heat exchanger. A battery of ten Metafilters, each filter having a bed of $1.5 \mathrm{~kg}$. of Farnell 14 charcoal and $2 \mathrm{~kg}$. Hyflo-Supercel, was used for the adsorption of streptomycin from each $1500 \mathrm{l}$. batch. The Metafilter beds were pretreated with $1800 \mathrm{l} .1 \cdot 2 \%(\mathrm{v} / \mathrm{v})$ aqueous phosphoric acid, followed by $1800 \mathrm{l}$. mains water, before being fed with the 
harvested metabolism fluid. The adsorption of streptomycin was effected at a flow-rate of $4000 \mathrm{l}$./hr., i.e. $400 \mathrm{l}$./hr./Metafilter.

First elution. The beds containing the adsorbed streptomycin were washed with $625 \mathrm{l}$. mains water, and eluted with $250 \mathrm{l} .1 \cdot 2 \%(\mathrm{v} / \mathrm{v})$ aqueous phosphoric acid, the first $50 \mathrm{l}$. of eluate being run to waste. The eluates were neutralized with $80 \%(\mathrm{w} / \mathrm{v})$ caustic soda and insoluble calcium phosphate removed by sedimentation.

Table 5. Mean stage potencies, and \% recoveries for twenty pilot-scale batches

\begin{tabular}{|c|c|c|c|c|c|}
\hline & $\begin{array}{c}\text { Mean } \\
\text { potency } \\
(\mu \mathrm{g} . / \mathrm{mg} .)\end{array}$ & $\begin{array}{c}\text { Total } \\
\text { strepto- } \\
\text { mycin } \\
\text { (g.) }\end{array}$ & Stage & $\begin{array}{c}\text { Stage } \\
\text { recovery } \\
(\%)\end{array}$ & $\begin{array}{c}\text { Overall } \\
\text { recovery } \\
(\%)\end{array}$ \\
\hline Culture filtrate* & $18 \cdot 2$ & 5928 & & - & - \\
\hline Phosphate eluate & - & 3263 & $\begin{array}{l}\text { Culture filtrate to phosphate } \\
\text { eluate }\end{array}$ & 55 & 55 \\
\hline Methanol eluate & 231 & 2595 & $\begin{array}{l}\text { Phosphate eluate to methanol } \\
\text { eluate }\end{array}$ & 80 & 44 \\
\hline Methanol concentrate & 362 & 2565 & $\begin{array}{l}\text { Methanol eluate to methanol } \\
\text { concentrate }\end{array}$ & 99 & 44 \\
\hline Precipitate & 422 & 2099 & $\begin{array}{l}\text { Methanol concentrate to } \\
\text { precipitate }\end{array}$ & 82 & 36 \\
\hline Freeze-dried product & $\begin{array}{l}389 \\
350 \cdot 5 \dagger\end{array}$ & 1635 & $\begin{array}{l}\text { Precipitate to freeze-dried } \\
\text { product }\end{array}$ & 77 & 28 \\
\hline
\end{tabular}

Second adsorption. Each 200 l. batch of neutralized and decanted phosphate eluate was agitated with $4 \%(\mathrm{w} / \mathrm{v})$ of previously acid-washed Farnell 14 charcoal, for $30 \mathrm{~min}$. The charcoal was collected on Doulton vacuum filters and washed with $100 \mathrm{l}$. distilled water, followed by $100 \mathrm{l}$. neutral methanol. This neutral methanol wash was generally used in three fractions, the first $60 \%(\mathrm{v} / \mathrm{v})$ methanol-water, the second $98 \%(\mathrm{v} / \mathrm{v})$ methanol-water, and the final wash with $100 \%$ methanol.

Acid-methanol elution. The water-free charcoal cake was suspended and agitated in $30 \mathrm{l}$. methanol, containing $2 \%(\mathrm{v} / \mathrm{v})$ conc. HCl. Elution was effected in $30 \mathrm{~min}$. The spent charcoal was recovered on a Doulton filter and the charcoal bed washed with three $10 \mathrm{l}$. washes of acid-methanol.

Concentration. The bulked eluate and washings were adjusted to $\mathrm{pH} 5-6$ with $80 \%(\mathrm{w} / \mathrm{v})$ caustic soda, and concentrated to one-eighth volume in a climbing film evaporator. The methanol concentrate, of 7-8 1., was filtered on a Buchner filter and the filtrate poured into $40 \mathrm{l}$. acetone. The precipitated streptomycin hydrochloride was filtered off, dried under reduced pressure, dissolved in pyrogen-free distilled water, Seitz-filtered, and freeze dried in phials, having approximately $160,000 \mu \mathrm{g}$./phial. Stage and overall recoveries and potencies are given in Table 5 . The overall and stage recoveries are calculated from the mean of twenty batches. The crude filtrate titres and final potencies were appreciably higher than the corresponding laboratory figures. The overall 
recovery from culture filtrate to freeze-dried product was lower than that obtained in the laboratory, but stage recoveries on the plant approximately paralleled those obtained in laboratory extractions. There was a significant increase in potencies during the concentration of methanol eluates.

We are indebted to Dr Tudor S. G. Jones for the spectrographic assay determinations of dried products, and Dr G. C. Ainsworth and Dr Tudor S. G. Jones for helpful criticism and advice. The pilot-scale production was carried out in the penicillin extraction plant designed by Dr C. G. Pope and Dr W. B. Hawes, and modified by us for the extraction of streptomycin.

\section{REFERENCES}

Ainsworth, G. C., Brown, A. M., Marsden, P.S.S. F., Smith, P.A.\& Spilsbury, J. F. (1947). A method for large-scale production of streptomycin by surface culture. J. gen. Microbiol. 1, 335.

Brown, A. M. \& Young, P. A. (1947). A dilution method for the assay of streptomycin. J. gen. Microbiol. 1, 353.

Carter, H. E., Clark, R. K. Jr., Dickman, S. R., Loo, Y. H., Skell, P. S. \& Strong, W. A. (1945). Isolation and purification of streptomycin. J. biol. Chem. $160,337$.

LePage, G. A. \& Campbell, E. (1946). Preparation of streptomycin. J. biol. Chem. $162,163$.

Waksman, S. A. \& Schatz, A. (1945). Streptomycin-origin, nature, and properties. J. Amer. pharm. Ass. 34, 273. 